(RESEARCH ARTICLE)

\title{
Prevalence of herpes simplex virus type 2 antibodies among pregnant women attending Federal Teaching Hospital, Ido-Ekiti, Nigeria
}

\author{
Oluboyo Bernard Oluwapelumi*, Fajuko Oluwadamilola Peace, Akele Richard Yomi, Akinseye Funmilayo \\ Janet and Oluboyo Adeola Olanrewaju
}

\begin{abstract}
Department of Medical Laboratory Science, College of Medicine and Health Sciences, Afe Babalola University, Ado-Ekiti, Ekiti State, Nigeria.
\end{abstract}

Publication history: Received on 09 April 2020; revised on 14 April 2020; accepted on 24 April 2020

Article DOI: https://doi.org/10.30574/wjarr.2020.6.1.0093

\begin{abstract}
Herpes simplex virus type 2 (genital herpes) is mostly asymptomatic except if the immune system is compromised. However, infections could lead to preterm delivery, low infant birth weight, still birth, hydrops, cystic brain degeneration, and fetal growth retardation. Record of the prevalence of the viral infection is scanty among pregnant women in Ekiti State, Nigeria. This study was conducted to determine the prevalence of herpes simplex virus type 2 antibodies among pregnant women attending Federal Teaching Hospital Ido-Ekiti. Structured questionnaires were administered to obtain information such as age, incidence of miscarriages, marital status and number of pregnancies among the women who were examined. Ninety (90) pregnant women were examined for the presence of herpes simplex virus type 2 (HSV-2) IgG and IgM antibodies using enzyme linked immunosorbent assay (ELISA) technique. Prevalence of HSV-2 IgG and IgM antibodies among pregnant women was $64.4 \%$ and $2.2 \%$ respectively. A significant (p<0.05) number of the pregnant women recorded presence of IgG antibody to the virus. There was no statistical significant ( $p>0.05$ ) difference between the prevalence of HSV-2 IgG antibody across age ranges, number of miscarriages, marital status and number of pregnancies. There may be need for antenatal screening of pregnant women for this virus in Ekiti State and perhaps generally in pregnancy to rule out the presence of genital herpes. With the risk of infection to fetus in mind, health policy makers may campaign against genital herpes to avert transmission of the virus to fetus before birth or after child birth.
\end{abstract}

Keywords: HSV-2; Pregnant women; Prevalence; Antibodies; HSV-2; Sexual behavior.

\section{Introduction}

Herpes simplex virus type 2 (HSV-2) is a universal, enveloped, and double stranded DNA virus, belonging to the family of Herpesviridae. It is the major cause of genital ulcers worldwide; causing principally anal and genital infections and may cause infections in other areas of the body [1].HSV infection is contracted through direct contact with an active lesion or body fluid of an infected person. Clinical manifestations of HSV include: skin and mucosa infection, genital herpes, herpetic whitlow, herpes encephalitis, cognitive deficits of bipolar disorder and Alzheimer's disease [2]. Immunocompromised patients are said to have more severe disease [3].

Herpes simplex virus-2 (genital herpes) genital infection is one of the most common and relevant venereal diseases occurring in women. After local replication at the infection site, HSV-2 establishes a lifetime latent infection, with recurring genital lesions and eventual systemic spreading [4]. When compared with an uninfected control population, a significant increase of spontaneous abortions has been described in women with latent HSV-2 genital infections [5]. The virus may also be transmitted from mother to child during childbirth [6]. However, the risk of infection transmission is minimal if the mother has no symptoms or exposed blisters during delivery. The risk is greater when the mother is infected with the virus for the first time during late pregnancy [7].

\footnotetext{
* Corresponding author: Oluboyo Bernard Oluwapelumi
} 
Preterm delivery and low infant birth weight have been reported in women with HSV asymptomatic genital shedding [8]. Abnormal accumulation of fluid in body tissues or cavities, cystic brain degeneration and idiopathic fetal growth retardation were all reported to be related to HSV-2 genital infection [9]. After parturition, HSV-2 infection of neonates born to infected mothers is perhaps the most deleterious complication of the disease.

HSV-2 seroprevalence has been reported as $6 \%$ in the general population and $14 \%$ in pregnant women [10]. The prevalence of HSV infection is said to increase with age, with the highest around 40 years [11]. Furthermore, it has been reported that age, educational status, parity, stage of pregnancy and history of blood transfusion were not significantly associated with the viral prevalence [12].

This infection appears to be related to the number of sexual partners, and with respect togender, infection is said to be more frequent in women than in men [13]. Moreover, ethnicity, poverty, cocaine abuse, earlier onset of sexual activity, sexual behaviour, and bacterial vaginosis are conditions capable of increasing a woman's possibility of infection before pregnancy [14]. Genital herpes during pregnancy has been linked with spontaneous abortion, intrauterine growth retardation, preterm labour, and congenital and neonatal herpes infections [15].

The major way of transmission of herpes simplex type 2 is through sexual intercourse. Herpes simplex for pregnant women can result in still birth. The long term effect of herpes simplex type 2 infections is very severe especially in women. Knowledge of the prevalence of herpes simplex virus type 2 among pregnant women in Ekiti State will certainly help the health sector of the economy in policy making towards the control of the diseases among pregnant women. Records are however scanty on the prevalence of herpes simplex virus type 2 among pregnant women in Ekiti State. The aim of this study therefore is to determine the prevalence of herpes simplex virus type 2 antibodies among pregnant women in Ekiti State.

\section{Material and methods}

\subsection{Study area}

This study was conducted at Federal Teaching Hospital Ido-Ekiti, Ekiti State, among pregnant women attending antenatal clinic in the hospital. Patients come from different parts of the State to the Teaching Hospital for medical attention. The latitude of Ido-Ekiti is 7.843093 and the longitude is 5.182314 [Distanceto.com (2020). Find Coordinates.https://www.distancesto.com/coordinates/ng/ido-ekiti-latitude-longitude/history/75944.htmllast accessed 04 April, 2020]. Laboratory analysis was carried out in the Medical Laboratories of the Department of Medical Laboratory Science, Afe Babalola University, Ado-Ekiti (ABUAD), Ekiti State. Ado-Ekiti is a city in southwestern Nigeria and lies on latitude $7^{\circ} 35$ and $7^{\circ} 38$ north of the equator and longitude $5^{\circ} 10$ and $5^{\circ} 15$ east of the Greenwich Meridian [16]. Afe Babalola University is a private institution with its campus located at $\mathrm{Km}$. 8.5, Afe Babalola way, opposite Federal Polytechnic, Ado-Ekiti.

\subsection{Ethical Consideration}

Ethical approval was sought for and obtained from the Federal Teaching Hospital, Ido-Ekiti, Ekiti State. The study participants were informed about the purpose of the study and written consent were obtained from each participant before sample collection.

\subsection{Eligibility Criteria}

Pregnant women attending FTH Ido-Ekiti, who consented to the study, were eligible for sampling. Non-pregnant women were excluded from the study.

\subsection{Sample size}

Ninety (90) pregnant women consented to the study and were enlisted.

\subsection{Application of questionnaire}

A semi structure questionnaire was used to collect the demographic data of the participants, risk factors and birth history. 


\subsection{Sample collection}

Five (5) ml of venous blood was collected from the cubital fossa of each of the consenting pregnant women using sterile needles, syringes and clean sample bottles. Serum was obtained by centrifuging each blood samples at $1000 \mathrm{rpm}$ (revolution per minute) for 10 minutes. The sera were stored in the Medical Microbiology Laboratory of the Department of Medical Laboratory Science, $\mathrm{ABUAD}$ at $-20^{\circ} \mathrm{C}$ until ready for assay [17].

\subsection{Sample analysis}

Analysis of the sample was carried out using HSV II IgG \& IgM ELISA kit (MELSIN MEDICAL CO., LIMITED, China).

\subsubsection{ELISA Assay principle [18].}

Into the appropriate microliter plate wells pre-coated with the antigen, samples, positive control, and negative control are added and incubated. After incubation, it is washed to remove the uncombined enzyme, after which chromogen solution A and B is added changing the colour of the liquid to blue. At the effect of a weak acid, the colour becomes yellow. The colour change is measured spectrophotometrically at a wavelength of $450 \mathrm{~nm}$. The presence or absence of IgG or IgM antibodies in the samples is determined by comparing the optical density (O.D) of the samples with the cutoff value.

\subsubsection{Test procedure for $\operatorname{Ig} G / \operatorname{Ig} M$}

The manufacturer's procedure was strictly followed. The reagents provided were allowed to attain room temperature for 15 minute before use. The wash buffer was diluted with distilled water using ratio 1: 20 before use. The microtiter plate was set up with 1 well as blank, 2 wells as negative control and 2 wells as positive control. $100 \mu$ of sample diluent was dispensed into the respective wells except the blank well, negative control well and positive control well. $100 \mu$ of the negative and positive controls were dispensed into their wells respectively. $10 \mu \mathrm{l}$ of samples was dispensed into their wells and the content was mixed by vibrating the plate gently.

The microplate was covered with a sealing paper and incubated in a microplate incubator (MARVOTECH PLATE INCUBATOR, China) at $37^{\circ} \mathrm{C}$ for 30 minutes [19]. After incubation, the microplate was washed five times using wash buffer. $100 \mu \mathrm{l}$ of conjugate was added to each well except the blank; the microplate was covered with a sealing paper and also incubated in a microplate incubator at $37^{\circ} \mathrm{C}$ for 30 minutes. After incubation the microplate was washed five times with the diluted wash buffer in an automatic plate washer (MARVOTECH PLATE WASHER, China)[19]. 50 $\mu$ l of substrate solution A and B was added to each well respectively and was mixed; the plate was covered and incubated at $37^{\circ} \mathrm{C}$ for 15 minutes. $50 \mu \mathrm{l}$ of stop solution was added to each well and mixed. The absorbance was read in an ELIZA reader machine (MARVOTECH ELIZA READER, China) at wavelength of $450 \mathrm{~nm}$ [19].

\subsubsection{Interpretation of result $\operatorname{Ig} G / \operatorname{Ig} M$}

If the mean negative control $0 . \mathrm{D} \leq 0.1$ and the mean positive control $0 . \mathrm{D} \geq 0.8$, the test is valid.

Cut-off O.D = the mean O.D value of the negative control $\times 2.1$

Positive results: Sample O.D $\geq$ cut-off O.D

Negative results: Sample O.D < cut-off O.D

\subsection{Statistical analysis}

Collected data were analyzed using statistical package for social science (SPSS) version 17. Chi square was used to compare age, miscarriage/stillbirth, number of pregnancies with prevalence of herpes simplex virus type 2 at 0.05 level of significance.

\section{Results}

The total prevalence of HSV-2 IgG was $58(64.4 \%)$. This was significantly higher $(\mathrm{p}<0.05)$ than the number of pregnant women that tested negative to HSV-2 IgG antibodies. The numbers of pregnant women that tested positive to HSV-2 IgM were $2(2.2 \%)$. This was not statistically significant ( $p>0.05)$. The two (2) positive IgM women were among those 58 women that tested positive to IgG.

Table 1 shows the prevalence of HSV-2 IgG and IgM antibodies across the age ranges of the pregnant women. The prevalence of IgG antibody was not significant ( $\mathrm{p}>0.05)$ across the age ranges of the pregnant women. However, prevalence was highest at age range 20-24 (75 \%) and lowest at age range 25-29 (60\%). Only two pregnant women were positive to HSV 2 IgM antibody and they occurred at age range 30-34 (6\%). 
The prevalence of HSV 2 IgG antibody among women who have had past history of miscarriages was not significant $(\mathrm{p}>0.05)$ in relation to women who had no miscarriages in the past (Table 2).

The percentage of pregnant unmarried women (single) that tested positive to HSV-2 IgG (76.9 \%) was not significantly higher ( $p>0.05$ ) in relation to that of pregnant married women (62.3\%) (Table 2). Prevalence of HSV-2 IgG antibodies among pregnant women in relation to number of pregnancies is shown in Table 2 . The prevalence of HSV-2 antibody among women that have had multiple pregnancies is not significant $(p>0.05)$ in relation to women who are just getting pregnant for the first time.

Table 1: Prevalence of HSV -2 IgG and IgM antibodies across the age ranges of pregnant women

\begin{tabular}{|c|c|c|c|c|c|c|}
\hline \multirow[t]{2}{*}{ Age ranges } & \multirow[t]{2}{*}{ Total } & \multicolumn{3}{|c|}{ IgG Antibodies } & \multirow[t]{2}{*}{$\chi^{2}$} & \multirow[t]{2}{*}{ p-value } \\
\hline & & Positive & Negative & Percentage positive & & \\
\hline $20-24$ & 8 & 6 & 2 & 75 & \multirow{6}{*}{11.574} & \multirow{6}{*}{0.868} \\
\hline $25-29$ & 30 & 18 & 12 & 60 & & \\
\hline $30-34$ & 33 & 21 & 12 & 64 & & \\
\hline $35-39$ & 16 & 11 & 5 & 69 & & \\
\hline $40-44$ & 3 & 2 & 1 & 67 & & \\
\hline \multirow[t]{2}{*}{ Total } & 90 & 58 & 32 & 64 & & \\
\hline & & \multicolumn{3}{|c|}{ IgM Antibodies } & & \\
\hline $20-24$ & 8 & 0 & 8 & 0 & \multirow{6}{*}{14.690} & \multirow{6}{*}{0.683} \\
\hline $25-29$ & 30 & 0 & 30 & 0 & & \\
\hline $30-34$ & 33 & 2 & 31 & 6 & & \\
\hline $35-39$ & 16 & 0 & 16 & 0 & & \\
\hline $40-44$ & 3 & 0 & 3 & 0 & & \\
\hline Total & 90 & 2 & 88 & 2 & & \\
\hline
\end{tabular}

Table 2: Prevalence of HSV-2 IgG antibodies among pregnant women in relation to miscarriages, marital status and number of pregnancies

\begin{tabular}{|c|c|c|c|c|c|}
\hline \multirow[b]{2}{*}{ Parameters } & \multicolumn{3}{|c|}{ IgG antibodies } & \multirow[b]{2}{*}{$\chi^{2}$} & \multirow[b]{2}{*}{ p-value } \\
\hline & Total & Positive (\%) & Negative (\%) & & \\
\hline \multicolumn{6}{|c|}{ Miscarriage status } \\
\hline Miscarriage & 15 & $7(46.7)$ & $8(53.3)$ & 2.483 & 0.115 \\
\hline No miscarriage & 75 & $51(68.0)$ & $24(32.0)$ & & \\
\hline \multicolumn{6}{|l|}{ Marital status } \\
\hline Married & 77 & $48(62.3)$ & $29(37.7)$ & 1.033 & 0.310 \\
\hline Single & 13 & $10(76.9)$ & $3(23.1)$ & & \\
\hline \multicolumn{6}{|c|}{ No. of pregnancies } \\
\hline Multiple & 44 & $29(65.9)$ & $15(34.1)$ & 0.081 & 0.776 \\
\hline Single & 46 & $29(63.0)$ & $17(37.0)$ & & \\
\hline
\end{tabular}




\section{Discussion}

An overall prevalence rate of $64.4 \%$ was recorded for HSV-2 IgG and $2.2 \%$ was recorded for HSV-2 IgM. The percentage of pregnant women having recent infection (presence of IgM) in the present study was low among those who tested positive to genital herpes IgG. The seroprevalence of the IgG is relatively high when they are compared with similar studies carried out in other States in Nigeria. There has been a report of $35.5 \%$ seroprevalence in a tertiary health facility in central Nigeria [12]. Also record of $46.3 \%$ seroprevalence among pregnant women in Benin, Nigeria [20] has been documented.

Findings in the present study was lower than $96.5 \%$ reported among pregnant women in urban health training Yopougon-Attie (Cote D'ivoire) [21] but higher than 63.1\% seroprevalence recorded among pregnant women in turkey [22] and 7.6-8.4 \% recorded in Italy [23]. Thus, seroprevalence vary from place to place. The finding in this study is comparable with the report obtained in Turkey but quite lower than is reported in Cote D'ivoire. The reason for the variation might be related to the rate of exposure to the virus, the prevalence of the virus in a particular locality, the rate of susceptibility to the virus and the immune status of individuals.

There was no statistically significant difference in infection across the ages of pregnant women. The records that genital herpes increase with age [11] did not appear supported by the present study. Infection can occur at any age if exposed to the virus. This is also supported by Oti and colleagues [12]. However, age range of 20-24 recorded the highest prevalence (75\%, Table 1) in the present study. This is in accordance with the work done at central Nigeria [12] and also with the work which was carried out in Port Harcourt, Nigeria [24]. This age group also coincided with the ages of marriageable ladies that are not yet married but were involved in premarital vaginal sex. Higher prevalence rate was recorded among such group than among married women (Table 2). The difference is however not statistically significant $(\mathrm{p}>0.05)$.

Also the prevalence of HSV 2 IgG antibody among women who have had miscarriages was not significant ( $p>0.05$ ) in relation to women who have had no miscarriages in the past. This report is in accord with other researcher's finding [25] but contradicted by the findings of Marquez and other researchers [26] who reported correlation between herpes simplex virus type 2 infection and miscarriages.

Although higher prevalence of HSV-2 antibodies were recorded among unmarried (single) pregnant women, the difference was not significant ( $p>0.05$ ). Record on prevalence of the virus in relation to single and married women are scanty. From this study it implied that both married and unmarried women are equally susceptible to HSV 2 infection. However, Kalu et al. [20] recoded statistically significant difference between the prevalence of HSV-2 infection among the married women and their unmarried counterparts.

The prevalence of HSV-2 antibody among women that have had multiple pregnancies was not significant ( $p>0.05$ ) in relation to women who are just getting pregnant for the first time in the present study. This is consistent with past records [12].

\section{Conclusion}

Prevalence of 64.4\% HSV type 2 IgG antibodies was recorded in this study among pregnant women in Ekiti State. A total of $2.2 \%$ of the examined pregnant women recorded recent infection (Presence of IgM). Prevalence was found not to be significant in relation to ages of the women, marital status, number of children (pregnancies), and past miscarriages. This study has provided information on the burden of HSV-2 infection among pregnant women attending Federal Teaching Hospital, Ido-Ekiti, Ekiti State, Nigeria.

\section{Compliance with ethical standards}

\section{Acknowledgments}

The cooperation of fellow Medical Laboratory Scientists in the Medical Microbiology Unit of the Department of Medical Laboratory Science in the storage of samples is appreciated.

\section{Disclosure of conflict of interest}

All authors declare no form of conflict of interest in this study. 


\section{Statement of ethical approval}

Ethical approval was sought for and obtained from the Federal Teaching Hospital, Ido-Ekiti, Ekiti State. The study participants were informed about the purpose of the study and written consent were obtained from each participant before sample collection. Regarding human subject researches, the procedures are in line with Helsink Declaration of 1975 , as revise in 2000; only blood samples were required from the consented participants.

\section{Statement of informed consent}

Informed consent was obtained from all individual participants included in the study.

\section{References}

[1] Chayavichitsilp P, Buckwalter JV, Krakowski AC and Friedlander SF. (2009). Herpes simplex. Pediatrics in Review, 30(4), 119-130.

[2] Dickerson FB, Boronow JJ, Stallings C, Origoni AE, Cole S, Krivogorsky B and Yolken RH. (2004). Infection with herpes simplex virus type 1 is associated with cognitive deficits in bipolar disorder. Biological Psychiatry, 55 (6), 588-593.

[3] Georg WA, Ursus NR, Annette S, Michael L, Dieter N and Gabriele K. (2005). Generalized herpes simplex virus infection in an immunocompromised patient-Report of a case and review of the literature. Pathology - Research Practice, 201(2), 123-129.

[4] Brugha R, Keersmaekers K and Meheus A. (1997). Genital herpes infection: a review. International Journal of Epidemiology, 26(4), 698-709.

[5] Bujko M, Sulovic V, Zivanovic V, Dotlic R and Bardic I. (2004). Herpes simplex virus herpes simplex virus (HSV) in aborted material using the polymerase chain reaction infection in women with previous spontaneous abortion. Journal of Perinatal Medicine, 16, 193-196.

[6] Corey L and Wald A. (2009). Maternal and Neonatal HSV Infections. New England Journal of Medicine, 361(14), 1376-1385.

[7] Kimberlin DW. (2007). Herpes simplex virus infections of the newborn. Seminars in Perinatology, 31(1), 19-25.

[8] Brown ZA, Benedetti J, Selke S, Ashley R, Watts DH and Corey L. (1996). Asymptomatic maternal shedding of herpes simplex virus at the onset of labor: relationship to preterm labor. Obsetrics and Gynecology, 87(4), 483488.

[9] Robb JA, Benirschke K, Mannino F and Voland J. (2013). Intrauterine latent herpes simplex virus infection: II. Latent neonatal infection. Human Pathology, 17 (12), 1210-1217.

[10] Cusini M, Cusan M, Parolin C, Livia S, Irene D, Carlo M, Barbara S and Giorgio P. (2000). Seroprevalence of herpes simplex virus type 2 infection among attendees of a sexually transmitted disease clinic in Italy. Sexually Transmitted Diseases, 27(5), 292-295.

[11] Cusini M and Ghislanzoni M. (2001). The importance of diagnosing genital herpes. Journal of Antimicrobial Chemotherapy, 471, 9-16.

[12] Oti VB, Usman BA, Pennap GR and Eno-Ibanga CK. (2017). Seroprevalance of Herpes simplex Virus Type-2 among Pregnant Women Accessing Antenatal Care in a Tertiary Healthcare Facility in Central Nigeria. Asian journal of Research in Medical and Pharmaceutical Sciences, 1(4), 1-6.

[13] Smith JS and Robinson NJ. (2002). Age-specific prevalence of infection with herpes simplex virus types 2 and 1 : a global review. Journal of Infectious Diseases. 186, 23-28.

[14] Cherpes TL, Meyn LA, Krohn MA, Lurie JG and Hillier SL. (2003). Association between acquisition of herpes simplex virus type 2 in women and bacterial vaginosis. Clinical Infectious Diseases, 30(10), 797-800.

[15] Ciavattini A, Vichi M, Rinci A and Tsiroglou D. (2007). Infezioni virali in gravidanza: gestionee raccomandazioni. La Colposcopia in Italia, 2, 11-16.

[16] Adebayo WO and Jegede AO. (2010). The environmental impact of flooding on transportation land use in Benin City, Nigeria. African Research Review, 4(1), 390-400. 
[17] Cheesbrough M. (2006). District Laboratory Practice in Tropical Countries, Part 2, Cambridge University Press, New York.

[18] Schmidt SD, Mazzella MJ, Nixon RA and Mathews PM. (2012). A $\beta$ measurement by enzyme-linked immunosorbent assay. Methods in Molecular Biology, 849, 507-527.

[19] Oluboyo OB, Musa HS, Akinseye JF, Akele RY, Oluboyo AO and Adewumi FA. (2019). Risky Sexual Behaviors and Prevalence of Chlamydia trachomatis Antibodies among Students in a Tertiary Institution. Online Journal of Health Allied Sciences, 18(3), 3.

[20] Kalu E, Ojide CK, Chuku A, Chukwunoye II, Agwu FE, Nwadike VU, Korie FC and Okafor GOC. (2015). Obstetric outcomes of human herpes virus-2 infection among pregnant women in Benin, Nigeria. Nigerian Journal of Clinical Practice, 18(4), 453-461.

[21] Borni C, Zaba F, Meite S, Mlan A, Inwoley K, Kouassi M’Bengue A, Sevede D, Faye Kette H and Dosso M. (2015). Seroprevalance of herpes simplex Virus 2 infection among pregnant women in urban health training YopougonAttie (Cote D'ivoire). Journal of Medical laboratory diagnosis, 6(3), 17-21.

[22] Nizami D, Yarkin F, Evruke C and Koksal F. (2004). Asymptomatic Herpes simplex virus type 2 infection among pregnant women in Turkey. Indian Journal of Medical Research, 120(2), 106-110.

[23] Suligoi B, Cusan M and Santopadre P. (2000). HSV-2 specific seroprevalence among various populations in Rome, Italy. The Italian herpes management forum. Sexually Transmitted Infections, 76(3), 213-214.

[24] Egbagba J and Mordi RM. (2015). Prevalence of asymptomatic genital herpes infection in women attending the antenatal clinics from the university of Port Harcourt Teaching Hospital, Port Harcourt, Nigeria. Researcher, $7(11), 35-42$.

[25] Giakoumelou S, Wheelhouse N, Cuschieri K, Entrican G, Howie SE and Horne AW. (2016). The role of infection in miscarriage. Human Reproduction update, 22(1), 116-133.

[26] Marquez L, Levy ML, Munoz FM and Palazzi DL. (2011). A report of three cases and review of intrauterine herpes simplex virus infection. The Pediatric Infectious Disease Journal, 30(2), 153-57.

\section{How to cite this article}

Oluboyo BO, Fajuko OP, Akele RY, Akinseye FJ and Oluboyo AO. (2020). Prevalence of herpes simplex virus type 2 antibodies among pregnant women attending Federal Teaching Hospital, Ido-Ekiti, Nigeria. World Journal of Advanced Research and Reviews, 6(1), 200-206. 